\title{
Effects of Different Light Sources on the Growth of Non-heading Chinese Cabbage (Brassica campestris L.)
}

\author{
Huimin Li \\ College of Agronomy, Nanjing Agricultural University. Nanjing, Jiangsu, 210095, China \\ E-mail:2009201005@njau.edu.cn \\ Canming Tang (Corresponding author) \\ College of Agronomy, Nanjing Agricultural University. Nanjing, Jiangsu, 210095, China \\ Tel: 86-258-486-0062Ｅ-mail: cmtang@yahoo.cn \\ Zhigang Xu (Corresponding author) \\ College of Agronomy, Nanjing Agricultural University. Nanjing, Jiangsu, 210095, China \\ E-mail: xuzhigang@njau.edu.cn \\ Xiaoying Liu \\ College of Agronomy, Nanjing Agricultural University. Nanjing, Jiangsu, 210095, China \\ E-mail: liuxy@njau.edu.cn
}

Xuelin Han

Kingsun, optoelectronic co.,ltd. Dongguan, Guangdong, 523565, China

E-mail: ks-hxl@kingsun-china.com

Received: December 23, 2011

Accepted: January 4, $2011 \quad$ Online Published: February 2, 2012

doi:10.5539/jas.v4n4p262

URL: http://dx.doi.org/10.5539/jas.v4n4p262

This research is supported by National Natural Science Fundation (30972035), the National 863 Plans Program (2011AA03A1), the National and Jiangsu Science and Technology Key Program (2011BAE01B00) and (BE2011197).

\begin{abstract}
To date, little is known about the effects of different light sources on the growth and quality of non-heading Chinese cabbage (Brassica campestris L.). The objective of present study was to evaluate the effects of light-emitting diodes (LEDs) light sources (blue, blue plus red, red), fluorescent lamps and sunlight on growth and vitamin $\mathrm{C}$, soluble protein, sucrose, soluble sugar, starch and pigment concentrations in non-heading Chinese cabbage seedlings. The dry mass of shoots and the fresh and dry masses of roots were highest in seedlings grown under red LEDs with weak lights. The fresh mass of roots and starch concentration were highest under red LEDs despite of the altered photosynthetic photo flux density (PPFD) levels. The concentrations of chlorophylls and vitamin $\mathrm{C}$ were greatest under blue LEDs with altered PPFD levels. The numbers of flower buds and open flowers were highest under red LEDs and blue plus red LEDs and were higher under LEDs than fluorescent lamps. The duration of flowering was highest under red LEDs and blue plus red LEDs. The present results demonstrate that LED light sources are more effective than fluorescent lamps for vegetative and reproductive growth of non-heading Chinese cabbage. Moreover, blue LEDs benefit vegetative growth, while red LEDs and
\end{abstract}


blue plus red LEDs support reproductive growth in non-heading Chinese cabbage. In the artificial cultivation and subsequent transplanting of the life cycle of plants, the light source can be selected to meet the requirements of different growth stages of plants and be used to promote the subsequent process in the industrial production of non-heading Chinese cabbage.

Keywords: Light-emitting diodes (LEDs), Non-heading Chinese cabbage, Vitamin C, Starch, Pigment, Flower bud

\section{Introduction}

Light plays a key role in plant life, determining their photo-morphogenesis and photosynthesis rate (Avercheva et al., 2009). The sun emits the most of its radiation in the visible range, it covers the range of wavelength from 400-700nm (Kolawole, et al., 2010). The integration, quality, duration and intensity of red, far-red, blue, UV-A $(320-500 \mathrm{~nm})$ and UV-B $(280-320 \mathrm{~nm})$ light have a profound influence on plants by triggering physiological reactions to control their growth and development (Briggs et al., 2001; Briggs and Olney, 2001; Clouse, 2001). LEDs are solid-state, long-lasting and durable sources of narrow-band light that can be used in a variety of horticultural and photo-biological applications (Stutte, 2009), including controlled research environments (Avercheva et al., 2009), lighting for tissue culture (Li et al., 2010) and supplemental and photoperiod lighting for greenhouses (Morrow, 2008). Because of their potential to be implemented in dynamic lighting strategies to control plant growth, development, physiological responses and production, it is important to learn more about the influence of light quality on these processes (Folta and Childers, 2008; Lefsrud et al., 2008; Massa et al., 2008).

Various studies have shown that LEDs have been successfully used for cultivation in several horticultural plant species, including lettuce (Bula et al., 1991; Hoenecke et al., 1992; Yanagi et al., 1996; Okamoto et al., 1997; Yorio et al., 2001; Kim et al., 2004; Kim et al., 2006; Stutte et al., 2009; Li and Kubota, 2009), cucumber (Menard et al., 2006; Brazaityte et al., 2009), pepper (Brown et al., 1995; Schuerger et al., 1997), spinach (Yorio et al., 2001), radish (Yorio et al., 2001; Tamulaitis et al., 2005), Chinese cabbage (Avercheva et al., 2009) and tomato (Kaneko-Ohashi et al., 2004; Menard et al., 2006; Brazaityte et al., 2010; Liu et al., 2011). Although previous studies have identified various physiological and morphological effects of light quality in many plant species, few reports have addressed the effect of LED light sources, sunlight and fluorescent lamps on the growth of non-heading Chinese cabbage (Brassica campestris L.). Non-heading Chinese cabbage originated from China and has a long cultivation history. Its leaves contain many beneficial materials, and it is an important cultivated vegetable species in China (Hu and Hou, 2010). Variations in light conditions will affect the metabolic processes such as growth and yield (Jaimez and Rada, 2011). The objective of the present study was to examine the effects of blue LEDs, red LEDs, blue plus red LEDs $(B: R=1: 8)$, fluorescent lamps and sunlight on the growth and quality of non-heading Chinese cabbage seedlings at different stages of development and to select the best light sources for the cultivation of seedlings under a controlled environment.

\section{Materials and Methods}

\subsection{Plant Materials}

The experiments were performed in a greenhouse at Nanjing Agricultural University with non-heading Chinese cabbage (Brassica campestris L.) cultivar 605. Seeds with a similar size were selected for sowing. Seeds were sown in cells filled with vermiculite and peat (1:1 by volume) for cultivation, with one seed per cell. After seven days, seedlings with two expanded cotyledons were transferred to the different lights.

\subsection{Light Treatments}

Seedlings were grown under red light-emitting diodes (LEDs), blue LEDs, a mixture of blue plus red LEDs $(B: R=1: 8)$ and fluorescent lamps. The growth temperature was set at $24-26^{\circ} \mathrm{C}$, and the relative humidity fluctuated between 40 and $50 \%$. The photoperiod was 12 hours. Seedlings were randomly assigned to each light treatment, and LEDs arrays were randomly assigned positions in the greenhouse. Seedlings of the first group were kept at a photosynthetic photo flux density (PPFD) of $80 \mu \mathrm{mol} \mathrm{m}^{-2} \mathrm{~s}^{-1}$ (weak light) for 60 days (60 days). Seedlings of the second group were first grown at weak light for 30 days, then transferred to sunlight (normal level of $350 \mu \mathrm{mol} \mathrm{m}^{-2} \mathrm{~s}^{-1}$ ) at the $31 \mathrm{st}$ day and cultured for 30 days (60 days). Seedlings of the third group were first grown at weak light for 30 days, then transferred to a normal level of sunlight on the 31 st day and cultured for 30 days, and then transferred to weak light on the 61st day until flowering (90, 120 days). Numbering the flower buds and open flowers was from $90^{\text {th }}$ to $120^{\text {th }}$ days. Each group had 30 seedlings. Each experiment was replicated three times. The spectral energy distribution of the blue plus red LEDs, blue LEDs, red LEDs, sunlight and fluorescent lamps was measured using an OPT-2000 spectral photometer (Optpeco, Beijing, China). FL: 
Fluorescent lamps. B+R: $11.1 \%$ blue plus $88.9 \%$ red LEDs. B: Blue LEDs. R: Red LEDs. a: Growth under LEDs and FL at a PPFD level of $80 \mu \mathrm{mol} \mathrm{m} \mathrm{m}^{-2} \mathrm{~s}^{-1}$ (weak light) for 60 days. b: Iinitial growth at a PPFD level of $80 \mu \mathrm{mol}$ $\mathrm{m}^{-2} \mathrm{~s}^{-1}$ for 30 days followed by sunlight for 30 days. c: Initial growth at a PPFD level of $80 \mu \mathrm{mol} \mathrm{m} \mathrm{s}^{-2}$ for 30 days followed by sunlight for 30 days and then weak light at 61 days until flowering.

(1) The blue plus red LEDs array (B+R) was supplied with $11.1 \%$ blue light with peak emission at $460 \mathrm{~nm}$ and $88.9 \%$ red light with peak emission at $660 \mathrm{~nm}$ ( $20 \mathrm{~nm}$ band-width at half-peak height).

(2) The blue LEDs array (B) was supplied with $100 \%$ blue light with peak emission at $460 \mathrm{~nm}(20 \mathrm{~nm}$ band-width at half-peak height).

(3) The red LEDs array (R) was supplied with 100\% red light with peak emission at $660 \mathrm{~nm}$ (20 nm band-width at half-peak height).

(4) The fluorescent lamp array (FL) was supplied a broad spectrum of light with peak emission at 400-700 nm.

(5) The sunlight light array (SUN) was supplied a mean PPFD of $350 \mu \mathrm{mol} \mathrm{m}{ }^{-2} \mathrm{~s}^{-1}$ with peak emission at 380-2600 nm.

\subsection{Growth Measurements}

Seedlings were destructively sampled after 60 (the first and second group) and 90 (the third group) days of growth. To determine dry mass, the seedlings were dried at $85^{\circ} \mathrm{C}$ until a constant mass was reached. The mass of each seedling was measured using an electronic balance.

For 2.4, 2.5, 2.6 and 2.7 measurements described below, seedlings were all destructively sampled after 60 (the first and second group) and 90 (the third group) days of growth. After sampling, leaves were weighed as required.

\subsection{Pigment Measurements}

Leaves were weighed to $0.1 \mathrm{~g}$ (fresh weight, $\mathrm{W}$ ), and $10 \mathrm{ml}(\mathrm{V})$ of $80 \%$ acetone was added to $0.1 \mathrm{~g}$ of leaf samples placed into a mortar with quartz sand. The chlorophyll was extracted until the leaf turned white. The optical density (OD) was measured with a UV-1200 spectrophotometer (Jin Peng, Shanghai, China) at $470 \mathrm{~nm}$ for carotenoid $\left(\mathrm{OD}_{470}\right)$, at $663 \mathrm{~nm}$ for chlorophyll a $\left(\mathrm{OD}_{663}\right)$, and at $645 \mathrm{~nm}$ for chlorophyll b $\left(\mathrm{OD}_{645}\right)$. The concentrations of chlorophyll $a$, chlorophyll $b$ and chlorophyll $(a+b)$ were determined using the following equations (Lichtenthaler and Wellburn, 1983):

Chlorophyll a $(\mathrm{mg} / \mathrm{g})=\left(12.72 \mathrm{OD}_{663}-2.59 \mathrm{OD}_{645}\right) \mathrm{V} / 1000 \mathrm{~W}$

Chlorophyll b $(\mathrm{mg} / \mathrm{g})=\left(22.88 \mathrm{OD}_{645}-4.67 \mathrm{OD}_{663}\right) \mathrm{V} / 1000 \mathrm{~W}$

Chlorophyll $(\mathrm{a}+\mathrm{b})(\mathrm{mg} / \mathrm{g})=\left(8.05 \mathrm{OD}_{663}+20.29 \mathrm{OD}_{645}\right) \mathrm{V} / 1000 \mathrm{~W}$

Carotenoid $(\mathrm{mg} / \mathrm{g})=\left(1000 \mathrm{OD}_{470}-3.27 \mathrm{C}_{\mathrm{a}}-104 \mathrm{C}_{\mathrm{b}}\right) \mathrm{V} /(229 \times 1000 \mathrm{~W})$

Where $\mathrm{V}$ is the total volume of acetone extract $(\mathrm{ml}), \mathrm{W}$ is the fresh weight $(\mathrm{g})$ of the sample, $\mathrm{C}_{\mathrm{a}}$ is the concentration of chlorophyll $\mathrm{a}$, and $\mathrm{C}_{\mathrm{b}}$ is the concentration of chlorophyll b (Li et al., 2010).

\subsection{Soluble Protein Measurements}

Leaves $(1.0 \mathrm{~g}$ of fresh weight, $\mathrm{W})$ were ground in a mortar with liquid nitrogen, to which $5 \mathrm{ml}\left(\mathrm{V}_{1}\right)$ of 0.067 $\mathrm{mol} / \mathrm{l}$ potassium phosphate buffer (PBS) was added, and were then filtered through filter paper. The extract was centrifuged at 12,000 g for $10 \mathrm{~min}$, and the supernatant was removed. The extract $\left(1 \mathrm{ml}, \mathrm{V}_{2}\right)$ and Coomassie brilliant blue G-250 (5 ml) was thoroughly mixed. The optical density was measured using a UV-1200 spectrophotometer at $595 \mathrm{~nm}$. To determine a standard curve, 0, 0.2, 0.4, 0.6, 0.8, and $1 \mathrm{ml}$ of $100 \mu \mathrm{g} / \mathrm{l}$ bovine serum albumin was added to 6 volumetric flasks, and distilled water was added to reach a volume of $1 \mathrm{ml}$. The optical density was measured by a UV-1200 spectrophotometer at $595 \mathrm{~nm}(\rho)$. The concentration of soluble protein was determined using the following equation: soluble protein $(\mathrm{mg} / \mathrm{g})=\rho \mathrm{V}_{1} / \mathrm{W} \mathrm{V}_{2}$ (Li et al., 2010).

\subsection{Vitamin C Measurements}

Leaves of $(1.0 \mathrm{~g}$, fresh weight, $\mathrm{W})$ were ground in a mortar with liquid nitrogen. Next, $5 \mathrm{ml}\left(\mathrm{V}_{1}\right)$ of $5 \%$ trichloroacetic acid (TCA) was added and the mixture was filtered through filter paper. The extract was centrifuged at 10,000 g for $10 \mathrm{~min}$, and the supernatant was removed. The extract $\left(1.0 \mathrm{ml}, \mathrm{V}_{2}\right)$ and $1.0 \mathrm{ml}$ of ethanol were thoroughly mixed. Next, $0.5 \mathrm{ml}$ of $0.4 \%$ phosphoric acid-ethanol, $1 \mathrm{ml}$ of $0.5 \% 1$, 10phenanthroline-ethanol and $0.5 \mathrm{ml}$ of $0.03 \mathrm{~g} / \mathrm{l}$ ferric chloride were added for a total volume of $5 \mathrm{ml}$. The optical density was measured using a UV-1200 spectrophotometer (Jin Peng, Shanghai, China) at $534 \mathrm{~nm}$. To obtain a standard curve, $0,0.2,0.4,0.6,0.8$, or $1 \mathrm{ml}$ of $100 \mathrm{mg} / \mathrm{l}$ bovine serum albumin was added to 6 volumetric flasks, 
and distilled water was added to reach a volume of $1 \mathrm{ml}$. The optical density was measured by a UV-1200 spectrophotometer at $534 \mathrm{~nm}(\rho)$. The concentration of vitamin $C$ was determined using the following equation: vitamin $\mathrm{C}$ concentration $(\mathrm{mg} / \mathrm{g})=\rho \mathrm{V}_{1} / \mathrm{W} \mathrm{V}_{2}$ (Li et al., 2010).

\subsection{Sugar and Starch Measurements}

Leaves $(0.5 \mathrm{~g}$, dry weight) were ground in a mortar with liquid nitrogen. Then $1 \mathrm{ml}$ of $80 \%$ ethanol was added, and the mixture was filtered through filter paper. The filtrates were recovered, and the residues were washed again with $70 \%$ ethanol and filtered. Both filtrates were mixed, and $3 \mathrm{ml}$ of distilled water was added. The extract was centrifuged at $12,000 \mathrm{~g}$ for $15 \mathrm{~min}$, and $1 \mathrm{ml}$ of supernatant was collected. Soluble sugar concentration was determined by the sulfuric acid-anthrone method and measured at $620 \mathrm{~nm}$. Sucrose concentration was determined using the phloroglucinol method and measured at $480 \mathrm{~nm}$ (Zhang, 2009). Takahashi's method was used for starch extraction (Takahashi et al., 1995). The residue obtained after ethanol extraction was resuspended with $0.1 \mathrm{~mol} / 1$ sodium acetate buffer $(\mathrm{pH} 4.8)$ and boiled for $20 \mathrm{~min}$. The gelatinized starch was digested with amyloglucosidase for four hours at $37^{\circ} \mathrm{C}$ and boiled again to stop the enzymatic reaction. After cooling, the mixture was centrifuged, and the amount of soluble sugar in the supernatant was determined by anthrone colorimetry ( $\mathrm{Li}$ et al., 2010). The starch concentration was estimated by converting glucose to starch equivalents using a factor of 0.9 .

\subsection{Statistical Analysis}

Statistical analyses were conducted with Statistical Product and Service Solutions (SPSS) for Windows, Version 16.0 (SPSS, Japan). Data were analyzed using analysis of variance (ANOVA), and the differences between means were tested using Tukey's Test $(\mathrm{P}<0.05)$.

\section{Results}

\subsection{The Growth of Non-heading Chinese Cabbage}

The effects of different light sources on growth of non-heading Chinese cabbage seedlings under a PPFD of 80 $\mu \mathrm{mol} \mathrm{m} \mathrm{s}^{-2} \mathrm{~s}^{-1}$ (weak light) for 60 days varied significantly (Table 1). The fresh mass of shoots was higher in seedlings grown under blue + red, blue and red LEDs and lower under fluorescent lamps. The dry mass of shoots and those of fresh and dry roots were greatest in seedlings under red LEDs and lowest under fluorescent lamps, an indication that LEDs light sources are more suitable for the growth of non-heading Chinese cabbage than fluorescent lamps and that red LEDs benefit biomass accumulation in non-heading Chinese cabbage.

Different light sources had variable effects on growth of non-heading Chinese cabbage seedlings that were first grown under weak light for 30 days and then transferred to sunlight for 30 days (Table 2). The dry masses of shoots and roots were greatest in seedlings under $B: R=1: 8$ LEDs and lowest under fluorescent lamps. The fresh mass of shoots and roots were greatest in seedlings under red LEDs and lowest under fluorescent lamps. This is an indication that $\mathrm{B}: \mathrm{R}=1: 8$ LEDs benefit the accumulation of dry biomass. The after-effects of different light sources on non-heading Chinese cabbage seedlings were obvious.

Different light sources had variable effects on growth of non-heading Chinese cabbage seedlings before flowering (Table 3). The fresh mass of shoots was greatest in seedlings under blue LEDs, whereas the fresh and dry masses of roots were greatest in seedlings under red LEDs and lowest under fluorescent lamps. For the shoot dry mass, red LEDs had similar higher; while fluorescent lamps gave the least shoot dry mass than any of the lights sources examined.

\subsection{The Concentrations of Pigments}

The leaf pigments of non-heading Chinese cabbage seedlings varied in response to the weak light. The leaf pigments also varied when they were first grown at weak light and then transferred to sunlight. The concentrations of chlorophyll a, chlorophyll $\mathrm{b}$, total chlorophyll and carotenoid were greatest in seedlings under blue LEDs (Figures 1a \& b).

Different light sources had variable effects on the concentrations of pigments in non-heading Chinese cabbage seedlings before blooming. The concentrations of chlorophyll $\mathrm{a}$, chlorophyll $\mathrm{b}$ and total chlorophyll were greatest in seedlings under blue LEDs and lowest in seedlings under fluorescent lamps (Figure c).

\subsection{Vitamin C Concentration}

The concentration of vitamin $\mathrm{C}$ was greatest in non-heading Chinese cabbage seedlings under blue plus red LEDs with weak light, followed by those under blue LEDs and lowest in seedlings under fluorescent lamps (Figure 2). The seedlings adapted to new illumination conditions with altered PPF levels. The concentration of 
vitamin $\mathrm{C}$ was greatest in seedlings under blue LEDs and lowest in seedlings under fluorescent lamps with altered PPF levels.

\subsection{Soluble Protein Concentration}

The concentration of soluble protein was highest under red LEDs in seedlings with the weak light, followed by fluorescent lamps and blue LEDs and lowest under blue plus red LEDs (Figure 3). The seedlings adapted to new illumination conditions with altered PPF levels. The concentration of soluble protein was greatest in seedlings under blue LEDs and blue plus red LEDs with altered PPF levels.

\subsection{Sugar and Starch Concentrations}

The sugar and starch concentrations of seedlings varied in response to different weak lights. Both concentrations also varied when seedlings were first grown at weak light and then transferred to sunlight. The concentrations of sucrose and soluble sugar were greatest in seedlings under blue LEDs, followed by those under red LEDs and blue plus red LEDs and lowest in seedlings under fluorescent lamps (Figures $4 \mathrm{a} \& \mathrm{~b}$ ). The starch concentration was greatest in seedlings under red LEDs.

The sugar and starch concentrations of seedlings varied in response to different lights before blooming. The concentrations of sucrose, soluble sugar and starch were greatest in seedlings grown under red LEDs, followed by those under blue plus red LEDs and lowest in seedlings under fluorescent lamps (Figure 4c). These results revealed that red LEDs are the best light source for accumulation of sucrose, starch and soluble sugar in non-heading Chinese cabbage.

\subsection{The Number of Flower Buds and the Duration of Flowering}

Different light sources had variable effects on the development of flowers in non-heading Chinese cabbage seedlings from 90 to 120 days (Table 4). The number of open flowers was highest in seedlings under red LEDs and blue plus red LEDs and the number of flower buds was higher in seedlings under LEDs than in those under fluorescent lamps. The duration of flowering was longest in seedlings under red LEDs and blue plus red LEDs.

\section{Discussion and Conclusion}

\subsection{Red LEDs Are the Best Light for Accumulation of Dry Mass and Photosynthates in Plants}

The present study demonstrated that red LEDs benefits the dry biomass accumulation of non-heading Chinese cabbage (Tables 1, $2 \& 3$ ). However, the present study are inconsistent with those previous studies (Brown et al., 1995; Goins et al., 1997; Okamoto et al., 1997; Yorio et al., 2001; Kim et al., 2004; Avercheva et al., 2009) that showed the best light sources for dry biomass accumulation are related to species or cultivars. LEDs lights show a significant superiority on plant growth and biomass. Red LEDs has variable effects on different plant species.

Light quality regulates the carbohydrate metabolism of higher plants, and carbohydrate content is increased under red light. The accumulation of starch in chloroplasts, which is enhanced by red light, may cause inhibition of photosynthesis (Kowallik et al., 1982). Red light may inhibit the translocation process of photosynthates (Saebo et al., 1995). The excess starch accumulation counters leaf photosynthesis (Bondada and Syvertsen, 2005). Red light enhances starch accumulation in Glycine and Sorghum species, the application of blue light sources is a means of studying the regulation of photosynthetic carbon metabolism in relation to plant growth (Britz and Sager, 1990). The present study, which is consistent with previous studies, reveal that the starch concentration is greatest in seedlings grown under red LEDs with altered PPFD levels (Figure 4) and red LEDs are advantageous to accumulation of starch in non-heading Chinese cabbage, moreover, the red LEDs benefits the accumulation of dry biomass in non-heading Chinese cabbage (Tables 1, $2 \& 3$ ). Red LEDs may promote accumulation of the photosynthetic products and the dry biomass but inhibit the translocation of photosynthetic products out of leaves; thus, the starch ultimately accumulated in leaves. Red LEDs may be used as the main light sources for reproductive growth of non-heading Chinese cabbage. In the artificial cultivation of plants, red LEDs may be the preferred light source, to get achieve a larger amount of dry matter and yield.

\subsection{The Effects of Blue LEDs on the Accumulation of Chlorophylls and the Quality of Plants}

The present results indicated that blue LEDs light is beneficial to pigment accumulation. The present results are consistent with previous studies (Senger, 1982; Saebo et al., 1995; Tanaka et al., 1998; Poudel et al., 2008; Kurilcik et al., 2008). Moreover, the blue LEDs play a key role in accumulation of chlorophylls.

The present results indicated that blue LEDs benefits vitamin C, sucrose and soluble sugar accumulation and nutritional quality of non-heading Chinese cabbage seedlings. LEDs light is beneficial to soluble protein accumulation and to nutritional quality of seedlings. The results in the present study demonstrate that blue LEDs benefits the accumulation of vitamin $\mathrm{C}$ and soluble protein, which are consistent with reports by Yang et al. 
(2010) and Zhang et al. (2010). However, the soluble sugar concentration was greatest under blue LEDs (Figure 4), which is inconsistent with the results of Yang et al. (2010) and Zhang et al. (2010). Blue LEDs benefits the accumulation of nutritional substances, and these effects may correlate with plant species or cultivars. The nutritional quality of plants could be varied by selecting special light sources under controlled growth environments. For the purpose of improving nutritional quality of vegetables, blue LEDs should be chosen as the preferred light source in artificial cultivation and subsequent transplanting of plants.

\subsection{Red LEDs Are the Best Light for Flowering}

Spectral quality has a major influence on induction rate of flower bud and subsequent development. The numbers of Cyclamen flower buds and open flowers were highest in plants grown under a mixture of blue plus red LEDs (B:R=10) compared with fluorescent lamps and other light sources (Heo et al., 2003). However, the development of visible flower buds in marigolds was about five times greater in fluorescent lamps than in blue or red LEDs (Heo et al., 2002). Monochromatic blue light delayed flowering in Arabidopsis possibly by influencing cryptochromes (Mockler et al., 1999). The present study showed that the number of flowers was highest in seedlings grown under red LEDs and blue plus red LEDs, and the number of flower buds was higher in seedlings grown under LEDs than fluorescent lamps (Table 4). Red LEDs and blue plus red LEDs are more suitable for flower opening in non-heading Chinese cabbage. The findings from the present study are consistent with those of Heo et al. (2003) and Mockler et al. (1999), but inconsistent with a report from Heo (2002). The shift in plants from vegetative growth to floral development is regulated by red-far-red light receptors (phytochromes) and blue-ultraviolet A light receptors (cryptochromes) (Guo et al., 1998). The present study also showed that the concentrations of sucrose and starch were greatest in seedlings grown under red LEDs before blooming and red LEDs benefitted dry biomass accumulation in non-heading Chinese cabbage. The number of flower buds and open flowers and the duration of flowering may correlate with the dry biomass and photosynthates, it regulated by different light receptors.

In conclusion, dry biomass and starch of non-heading Chinese cabbage accumulate under red LEDs light sources. In addition, red LEDs also benefits the flower opening. The pigment and nutritional substances (vitamin C, soluble sugar and soluble protein) accumulate under blue LEDs light sources. Red LEDs should be selected as the preferred light source in the artificial cultivation and subsequent transplanting of plants to obtain a higher biomass and more flowers. By contrast, blue LEDs should be used as the preferred light source for higher nutritional quality to improve the growth and development of plants.

\section{References}

Avercheva, O.V., Berkovich, Y.A., Erokhin, A.N., Zhigalova, T.V., Pogosyan, S.I., \& Smolyanina, S.O. (2009). Growth and photosynthesis of Chinese cabbage plants grown under light-emitting diode-based light source. Russian Journal of Plant Physiology, 56, 14-21. http://dx.doi.org/10.1134/S1021443709010038

Bondada, B.R., \& Syvertsen, J.P. (2005). Concurrent changes in net $\mathrm{CO}_{2}$ assimilation and chloroplast ultrastructure in nitrogen deficient citrus leaves. Environmental and Experimental Botany, 54, 41-48. http://dx.doi.org/10.1016/j.envexpbot.2004.05.005.

Brazaityte, A., Duchovskis, P., Urbonaviciute, A., Samuoliene, G., Jankauskiene, J., Kasiuleviciute-Bonakere, A., Bliznikas, Z., Novickovas, A., Breive, K., \& Zukauskas, A. (2009). The effect of light-emitting diodes lighting on the growth of cucumber transplants and after-effect on yield. Zemdirbyste Agriculture, 96, 102-118. http://zemdirbyste-agriculture.lzi.lt/96(3)tomas/96_3_tomas_102_118.pdf

Brazaityte, A., Duchovskis, P., Urbonaviciute, A., Samuoliene, G., Jankauskiene, J., Sakalauskaite, J., Sabajeviene, G., Sirtautas, R., \& Novickovas, A. (2010). The effect of light-emitting diodes lighting on the growth of tomato transplants. Zemdirbyste Agriculture, $\quad 97, \quad 89-98$. http://www.lzi.lt/tomai/97(2)tomas/97_2_tomas_str10.pdf

Briggs, W.R., Beck, C.F., Cashmore, A.R., Christie, J.M., \& Hunghes, J. (2001). The phototropin family of photoreceptors. Plant Cell, 13, 993-997. http://dx.doi.org/10.1105/tpc.13.5.993

Briggs, W.R., \& Olney, M.A. (2001). Photoreceptors in plant photomorphogenesis to date, five photochromes, two cryptochrome, one phototropin and one superchrome. Plant Physiology, 25, 85-88. http://dx.doi.org/10.1104/pp.125.1.85

Britz, S.J., \& Sage, J.C. (1990). Photomorphogenesis and photoassimilation in soybean and sorghum grown under broad spectrum or blue-deficient light sources. Plant Physiology, 94, 448-454. http://www.jstor.org/stable/4273112 
Brown, C.S., Schuerger, A.C., \& Sager, J.C. (1995). Growth and photomorphogenesis of pepper plants under red light-emitting diodes with supplemental blue or far-red lighting. Journal of the American Society of Horticultural Science, 120, 808-813. http://www.ncbi.nlm.nih.gov/pubmed/11540133

Bula, R.J., Morrow, R.C., Tibbitts, T.W., Barta, D.J., Ignatius, R.W., \& Martin, T.S. (1991). Light-emitting diodes as a radiation source for plants. HortScience, 26, 203-205. http://www.ncbi.nlm.nih.gov/pubmed/11537727

Clouse, S.D. (2001). Integration of light and brassinosteroid signals in etiolated seedling growth. Trends in Plant Science, 6, 443-445. http://dx.doi.org/10.1016/S1360-1385(01)02102-1

Folta, K.M., \& Childers, K.S. (2008). Light as a growth regulator: controlling plant biology with narrow-bandwidth solid-state lighting systems. HortScience, 43, 1957-1964. http://hortsci.ashspublications.org/content/43/7/1957.full

Goins, G.D., Yorio, N.C., Sanwo, M.M., Brown, C.S., \& Sager, J.C. (1997). Photomorphogenesis, photosynthesis, and seed yield of wheat plants grown under red light-emitting diodes (LEDs) with and without supplemental blue lighting. Journal of experimental botany, 48, 1407-1413. http://dx.doi.org/10.1093/jxb/48.7.1407

Guo, H., Yang, H., Mockler, T.C., \& Lin, C. (1998). Regulation of flowering time by Arabidopsis photoreceptors. Science, 279, 1360-1363. http://dx.doi.org/10.1126/science.279.5355.1360

Heo, J., Lee, C., Chakrabarty, D., \& Paek, K. (2002). Growth responses of marigold and salvia bedding plants as affected by monochromic or mixture radiation provided by a light emitting diode (LED). Plant Growth Regulation, 38, 225-230. http://dx.doi.org/10.1023/A:1021523832488

Heo, J., Lee, C., Chakrabarty, D., \& Paek, K. (2003). Influence of light quality and photoperiod on flowering of Cyclamen persicum Mill. cv. 'Dixie White'. Plant Growth Regulation, 40, 7-10. http://dx.doi.org/10.1023/A:1023096909497

Hoenecke, M.E., Bula, R.J., \& Tibbits, T.W. (1992). Importance of 'blue' photon levels for lettuce seedlings

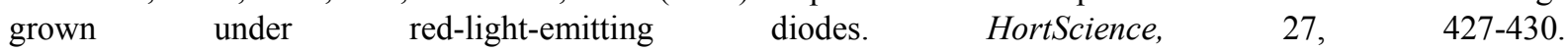
http://www.ncbi.nlm.nih.gov/pubmed/11537611

Hu, C.M., \& Hou, X.L. (2010). Relationship of major nutrient components with low temperature tolerance in non-heading Chinese cabbage. Journal of Nanjing Agricultural University, 33, 37-41. (in Chinese with English Abstract). http://nauxb.njau.edu.cn

Jaimez, R.E., \& Rada, F. (2011). Gas exchange in Sweet Pepper (Capsicum chinense Jacq) under different light conditions. Journal of Agricultural Science, 3, 134-142. http://dx.doi.org/10.5539/jas.v3n3p134

Kaneko-Ohashi, K., Fujiwara, K., Kimura, Y., Matsuda, R., \& Kurata, K. (2004). Effects of red and blue LEDs low light irradiation during low temperature storage on growth, ribulose-1, 5-bisphosphate carboxylase/oxygenase content, chlorophyll content and carbohydrate content of grafted tomato plug seedlings. Environmental Control in Biology, 42, 65-73. http://sciencelinks.jp/j-east/article/200704/000020070407A0032357.php

Kim, H.H., Goins, G.D., Wheeler, R.M., \& Sager, J.C. (2004). Green-light supplementation for enhanced lettuce growth under red- and blue-light-emitting diodes. HortScience, 39, 1617-1622. http://www.ncbi.nlm.nih.gov/pubmed/15770792

Kim, H.H., Wheeler, R.M., Sager, J.C., Goins, G.D., \& Norikane, J.H. (2006). Evaluation of lettuce growth using supplemental green light with red and blue light-emitting diodes in a controlled environment-a review of research at Kennedy Space Center. Acta Horticulturae, 711, 111-119. http://www.actahort.org/members/showpdf?booknrarnr=711_11

Kolawole, O. M., Kayode, R. M. O., \& Aina, J. (2010). The drying effect of varying light frequencies on the proximate and microbial composition of tomato. Journal of Agricultural Science, 2, 214-224. http://www.ccsenet.org/jas

Kowallik, W. (1982). Blue light effects on respiration. Annual Review of Plant Physiology, 33, 51-72. http://dx.doi.org/10.1146/annurev.pp.33.060182.000411

Kurilcik, A., Miklusyte-Canova, R., Dapkuniene, S., Zilinskaite, S., Kurilcik, G., Tamulaitis, G., Duchovskis, P., \& Zukauskas, A. (2008). In vitro culture of Chrysanthemum plantlets using light-emitting diodes. Central European Journal Biology, 3, 161-167. http://dx.doi.org/10.2478/s11535-008-0006-9

Lefsrud, M.G., Kopsell, D.A., \& Sams, C.E. (2008). Irradiance from distinct wavelength light-emitting diodes affect secondary metabolites in Kale. HortScience, 43, 2243-2244. http://trace.tennessee.edu/utk_planpubs/6 
Li, H. M., Xu, Z. G., \& Tang, C. M. (2010). Effect of light-emitting diodes on growth and morphogenesis of upland cotton (Gossypium hirsutum L.) plantlets in vitro. Plant Cell Tissue Orgure Culture, 103, 155-163. http://dx.doi.org/10.1007/s11240-010-9763-z

Li, Q., \& Kubota, C. (2009). Effects of supplemental light quality on growth and phytochemicals of baby leaf lettuce. Environmental and Experimental Botany, 67, 59-64. http://dx.doi.org/10.1016/j.envexpbot.2009.06.011

Lichtenthaler, H., \& Wellburn, A. (1983). Determinations of total carotenoids and chlorophylls $a$ and $b$ of leaf extracts in different solvents $603^{\text {rd }}$ meeting, Liverpool England.

Liu, X.Y., Guo, S.R., Xu, Z.G., Jiao, X.L., \& Takafumi, T. (2011). Regulation of chloroplast ultrastructure, cross-section anatomy of leaves, and morphology of stomata of cherry tomato bydifferent light irradiations of light-emitting diodes. Hortscience, 46, 1-5. http://hortsci.ashspublications.org/content/46/2/217.full

Massa, G.D., Kim, H.H., Wheeler, R.M., \& Mitchell, C.A. (2008). Plant productivity in response to LED lighting. HortScience, 43, 1951-1956. http://hortsci.ashspublications.org/content/43/7/1951.full

Menard, C., Dorais, M., Hovi, T., \& Gosselin, A. (2006). Developmental and physiological responses of tomato and cucumber to additional blue light. Acta Horticulturae, 711, 291-296. http://www.actahort.org/books/711/711_39.htm

Mockler, T.C., Guo, H., Yang, H., Duong, H., \& Lin, C. (1999). Antagonistic action of Arabidopsis cytochromes and phytochrome B in the regulation of floral induction. Development, 126, 2073-2082. http://dx.doi.org/10.1190/1.1438986

Morrow, R.C. (2008). LED Lighting in Horticulture. HortScience, 43, 1947-1950. http://hortsci.ashspublications.org/content/43/7/1947.full

Okamoto, K., Yanagi, T., \& Kondo, S. (1997). Growth and morphogenesis of lettuce seedlings raised under different combinations of red and blue light. Acta Horticulturae, 435, 149-157. http://www.actahort.org/books/435/435_14.htm

Poudel, P.R., Kataoka, I., \& Mochioka, R. (2008). Effect of red-and blue-light-emitting diodes on growth and morphogenesis of grapes. Plant Cell Tissue Organ Culture, 92, 147-153. http://dx.doi.org/10.1007/s11240-007-9317-1

Saebo, A., Krekling, T., \& Appelgren, M. (1995). Light quality affects photosynthesis and leaf anatomy of birch plantlets in vitro. Plant Cell Tissue Organ Culture, 41, 177-185. http://dx.doi.org/10.1007/BF00051588

Schuerger, A.C., Brown, C.S., \& Stryjewski, E.C. (1997). Anatomical features of pepper plants (Capsium annuum L.) grown under red lightemitting diodes supplemented with blue or far-red light. Annals of Botany, 79, 273-282. http://dx.doi.org/10.1006/anbo.1996.0341

Senger, H. (1982). The effect of blue light on plants and microorganisms. Photochemistry and Photobiology, 35, 911-920. http://dx.doi.org/10.1111/j.1751-1097.1982.tb02668.x

Stutte, G.W. (2009). Light-emitting diodes for manipulating the phytochrome apparatus. HortScience, 44, 231-234. http://hortsci.ashspublications.org/content/44/2/231.full

Stutte, G.W., Edney, S., \& Skerritt, T. (2009). Photoregulation of bioprotectant content of red leaf lettuce with light-emitting diodes. HortScience, 44, 79-82. http://hortsci.ashspublications.org/content/44/1/79.full

Takahashi, K., Fujino, K., Kikuta, Y., \& Koda, Y. (1995). Involvement of the accumulation of sucrose and the synthesis of cell wall polysaccharides in the expansion of potato cells in response to jasmonic acid. Plant Science, 111, 11-18. http://dx.doi.org/10.1016/0168-9452(95)04222-G

Tamulaitis, G., Duchovskis, P., Bliznikas, Z., Breive, K., Ulinskaite, R., Brazaityte, A., Novickovas, A., \& Zukauskas, A. (2005). High-power light-emitting diode based facility for plant cultivation. Journal of Physics D: Applied Physics, 38, 3182-3187. http://dx.doi.org/10.1088/0022-3727/38/17/S20

Tanaka, M., Takamura, T., Watanabe, H., Endo, M., Yanagi, T., \& Okamoto, K. (1998). In vitro growth of Cymbidium plantlets cultured under super bright and blue light-emitting diodes (LEDs). Journal of Horticultural Science and Biotechnology, 73, 39-44. http://www.defra.gov.uk/

Yanagi, T., Okamoto, K., \& Takita. S. (1996). Effects of blue, red and blue/red lights of two different PPF levels on growth and morphogenesis of lettuce plants. Acta Horticulturae, 440, 117-122. http://www.ncbi.nlm.nih.gov/pubmed/11541565

Yang, X.J., Liu, S.Q., Zhang, Z.K., Ma, L., Zhang, Y., \& Wei, H. (2010). Effects of different light emitting 
diode sources on nutritional quality of garlic seedling. Acta Nutrimenta Sinica, 32, 518-520. (in Chinese with English Abstract). http://mall.cnki.net/magazine/Article/YYXX201005031.htm

Yorio, N.C., Goins, G.D., Kagie, H.R., Wheeler, R.M., \& Sager, J.C. (2001). Improving spinach, radish, and lettuce growth under red light-emitting diodes (LEDs) with blue light supplementation. HortScience, 36, 380-383. http://www.ncbi.nlm.nih.gov/pubmed/12542027

Zhang, L.W., Liu, S.Q., Zhang, Z.K., Yang, R., \& Yang, X.J. (2010). Dynamic effects of different light qualities on pea sprouts quality. Northern Horticulture, 8: 4-7. (in Chinese with English Abstract). http://www.cnki.com.cn/Article/CJFDTOTAL-BFYY201008003.htm

Zhang, Y. S., Huang, X., \& Chen, Y. F. (2009). Experimental course of plant physiology. Higher Education Press, Beijing (in Chinese).

Table 1. The effects of different lights on the mass of non-heading Chinese cabbage seedling growth under a PPFD level of $80 \mu \mathrm{mol} \mathrm{m} \mathrm{s}^{-2}$ for 60 days

\begin{tabular}{|l|c|c|c|c|}
\hline $\begin{array}{l}\text { Light } \\
\text { treatment }\end{array}$ & $\begin{array}{c}\text { Shoot fresh mass } \\
(\mathrm{g})\end{array}$ & $\begin{array}{c}\text { Shoot dry mass } \\
(\mathrm{g})\end{array}$ & $\begin{array}{c}\text { Root fresh mass } \\
(\mathrm{g})\end{array}$ & $\begin{array}{c}\text { Root dry mass } \\
(\mathrm{g})\end{array}$ \\
\hline FL & $1.38 \mathrm{~b}$ & $0.23 \mathrm{c}$ & $0.13 \mathrm{~d}$ & $0.02 \mathrm{~d}$ \\
\hline $\mathrm{B}+\mathrm{R}$ & $5.28 \mathrm{a}$ & $0.53 \mathrm{~b}$ & $0.95 \mathrm{~b}$ & $0.11 \mathrm{~b}$ \\
\hline B & $6.67 \mathrm{a}$ & $0.49 \mathrm{~b}$ & $0.61 \mathrm{c}$ & $0.08 \mathrm{c}$ \\
\hline R & $5.93 \mathrm{a}$ & $0.73 \mathrm{a}$ & $1.08 \mathrm{a}$ & $0.14 \mathrm{a}$ \\
\hline
\end{tabular}

Different letters within the column indicate significant differences at $\mathrm{P}<0.05$ according to Tukey's test.

Table 2. The effects of sunlight on the mass of non-heading Chinese cabbage seedlings that were first grown at a PPFD level of $80 \mu \mathrm{mol} \mathrm{m}^{-2} \mathrm{~s}^{-1}$ for 30 days and then transferred to sunlight for 30 days

\begin{tabular}{|l|c|c|c|c|}
\hline $\begin{array}{l}\text { Light } \\
\text { treatment }\end{array}$ & $\begin{array}{c}\text { Shoot fresh mass } \\
(\mathrm{g})\end{array}$ & $\begin{array}{c}\text { Shoot dry mass } \\
(\mathrm{g})\end{array}$ & $\begin{array}{c}\text { Root fresh mass } \\
(\mathrm{g})\end{array}$ & $\begin{array}{c}\text { Root dry mass } \\
(\mathrm{g})\end{array}$ \\
\hline FL & $3.69 \mathrm{c}$ & $0.33 \mathrm{c}$ & $0.33 \mathrm{c}$ & $0.04 \mathrm{~d}$ \\
\hline $\mathrm{B}+\mathrm{R}$ & $10.95 \mathrm{~b}$ & $0.96 \mathrm{a}$ & $0.93 \mathrm{~b}$ & $0.15 \mathrm{a}$ \\
\hline $\mathrm{B}$ & $11.79 \mathrm{~b}$ & $0.75 \mathrm{~b}$ & $0.90 \mathrm{~b}$ & $0.10 \mathrm{~b}$ \\
\hline $\mathrm{R}$ & $13.60 \mathrm{a}$ & $0.80 \mathrm{~b}$ & $1.40 \mathrm{a}$ & $0.06 \mathrm{c}$ \\
\hline
\end{tabular}

Different letters within the column indicate significant differences at $\mathrm{P}<0.05$ according to Tukey's test.

Table 3. The effects of different lights on the mass of non-heading Chinese cabbage seedlings that were first grown at a PPFD level of $80 \mu \mathrm{mol} \mathrm{m} \mathrm{s}^{-2}$ (weak light) for 30 days, then under sunlight for 30 days and, finally, under weak light at 61 days until flowering

\begin{tabular}{|l|c|c|c|c|}
\hline $\begin{array}{l}\text { Light } \\
\text { treatment }\end{array}$ & $\begin{array}{c}\text { Shoot fresh mass } \\
(\mathrm{g})\end{array}$ & $\begin{array}{c}\text { Shoot dry mass } \\
(\mathrm{g})\end{array}$ & $\begin{array}{c}\text { Root fresh mass } \\
(\mathrm{g})\end{array}$ & $\begin{array}{c}\text { Root dry mass } \\
(\mathrm{g})\end{array}$ \\
\hline FL & $0.61 \mathrm{c}$ & $0.04 \mathrm{c}$ & $0.04 \mathrm{c}$ & $0.01 \mathrm{c}$ \\
\hline $\mathrm{B}+\mathrm{R}$ & $6.83 \mathrm{~b}$ & $0.71 \mathrm{~b}$ & $1.36 \mathrm{~b}$ & $0.18 \mathrm{~b}$ \\
\hline B & $9.73 \mathrm{a}$ & $0.76 \mathrm{ab}$ & $1.21 \mathrm{~b}$ & $0.20 \mathrm{~b}$ \\
\hline $\mathrm{R}$ & $6.57 \mathrm{~b}$ & $0.87 \mathrm{a}$ & $1.71 \mathrm{a}$ & $0.24 \mathrm{a}$ \\
\hline
\end{tabular}

Different letters within the column indicate significant differences at $\mathrm{P}<0.05$ according to Tukey's test. 
Table 4. The Number of flower buds and open flowers per plant in non-heading Chinese cabbage seedlings grew under different lights until flowering (90-120 days)

\begin{tabular}{|l|l|l|l|l|l|l|l|l|}
\hline \multirow{2}{*}{$\begin{array}{l}\text { Light } \\
\text { treatment }\end{array}$} & \multicolumn{4}{|c|}{ Numbers of open Flowers } & \multicolumn{4}{c|}{ Numbers of flower buds } \\
\cline { 2 - 9 } & $0 \mathrm{~d}$ & $10 \mathrm{~d}$ & $20 \mathrm{~d}$ & $30 \mathrm{~d}$ & $0 \mathrm{~d}$ & $10 \mathrm{~d}$ & $20 \mathrm{~d}$ & $30 \mathrm{~d}$ \\
\hline FL & $0 \mathrm{a}$ & $0 \mathrm{~b}$ & $5 \mathrm{bc}$ & $8 \mathrm{a}$ & $2 \mathrm{a}$ & $4 \mathrm{a}$ & $0 \mathrm{~b}$ & $0 \mathrm{a}$ \\
\hline $\mathrm{B}+\mathrm{R}$ & $2 \mathrm{a}$ & $5 \mathrm{a}$ & $9 \mathrm{ab}$ & $11 \mathrm{a}$ & $3 \mathrm{a}$ & $5 \mathrm{a}$ & $2 \mathrm{ab}$ & $2 \mathrm{a}$ \\
\hline $\mathrm{B}$ & $0 \mathrm{a}$ & $0 \mathrm{~b}$ & $3 \mathrm{c}$ & $9 \mathrm{a}$ & $1 \mathrm{a}$ & $7 \mathrm{a}$ & $7 \mathrm{a}$ & $2 \mathrm{a}$ \\
\hline $\mathrm{R}$ & $2 \mathrm{a}$ & $5 \mathrm{a}$ & $10 \mathrm{a}$ & $11 \mathrm{a}$ & $3 \mathrm{a}$ & $5 \mathrm{a}$ & $2 \mathrm{ab}$ & $0 \mathrm{a}$ \\
\hline
\end{tabular}

Different letters within the column indicate significant differences at $\mathrm{P}<0.05$ according to Tukey's test.

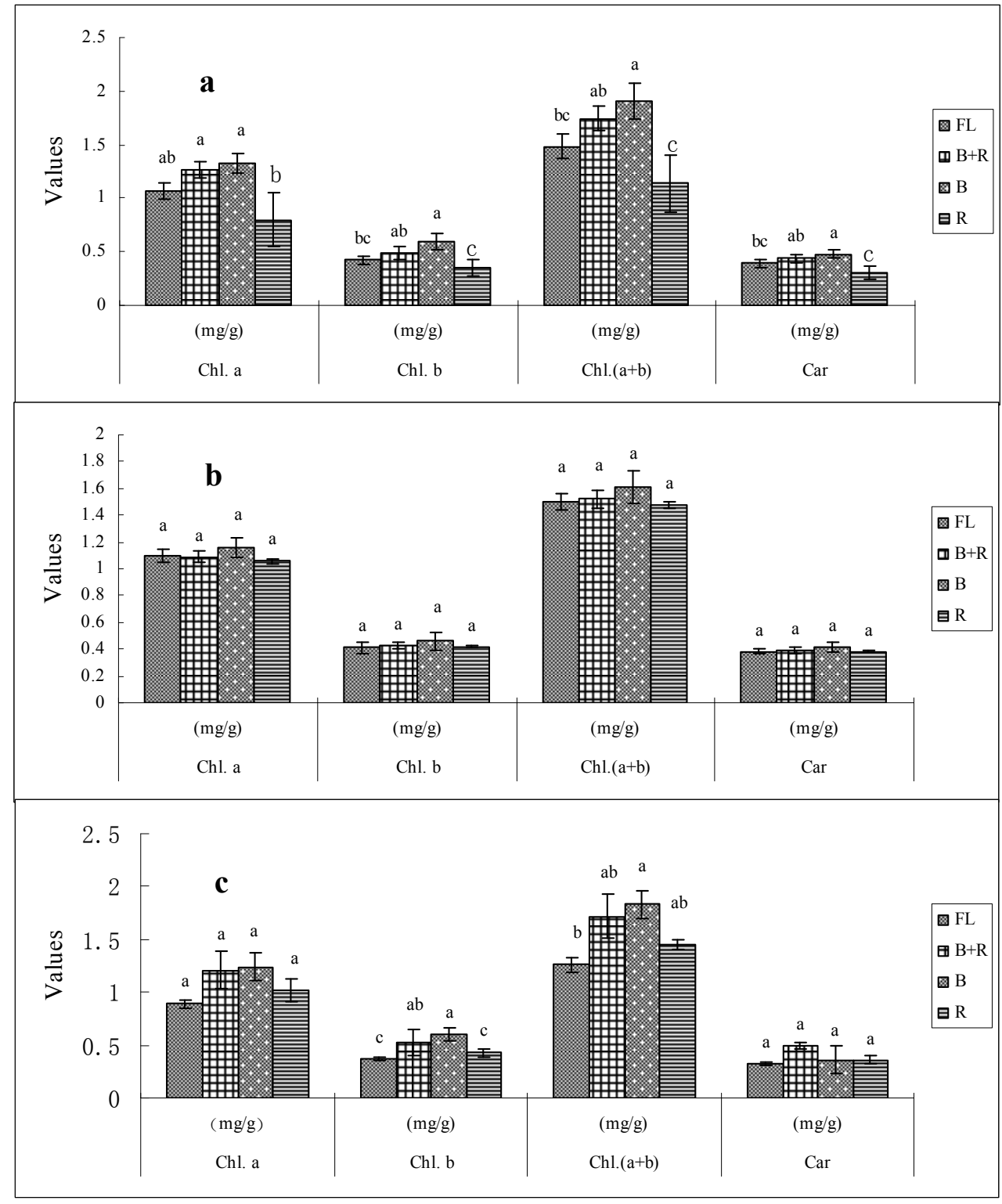

Figure 1. The effects of different lights on the pigment concentrations of non-heading Chinese cabbage seedlings with different PPFD levels, growth under LEDs and FL at a PPFD level of $80 \mu \mathrm{mol} \mathrm{m} \mathrm{s}^{-1}$ for 60 days (a), initial growth at a PPFD level of $80 \mu \mathrm{mol} \mathrm{m} \mathrm{s}^{-1}$ for 30 days followed by sunlight for 30 days (b) and initial growth at a PPFD level of $80 \mu \mathrm{mol} \mathrm{m} \mathrm{m}^{-2}$ for 30 days followed by sunlight for 30 days and then weak light at 61 days until flowering (c)

Different letters within the column indicate significant differences at $\mathrm{P}<0.05$ according to Tukey's test. 


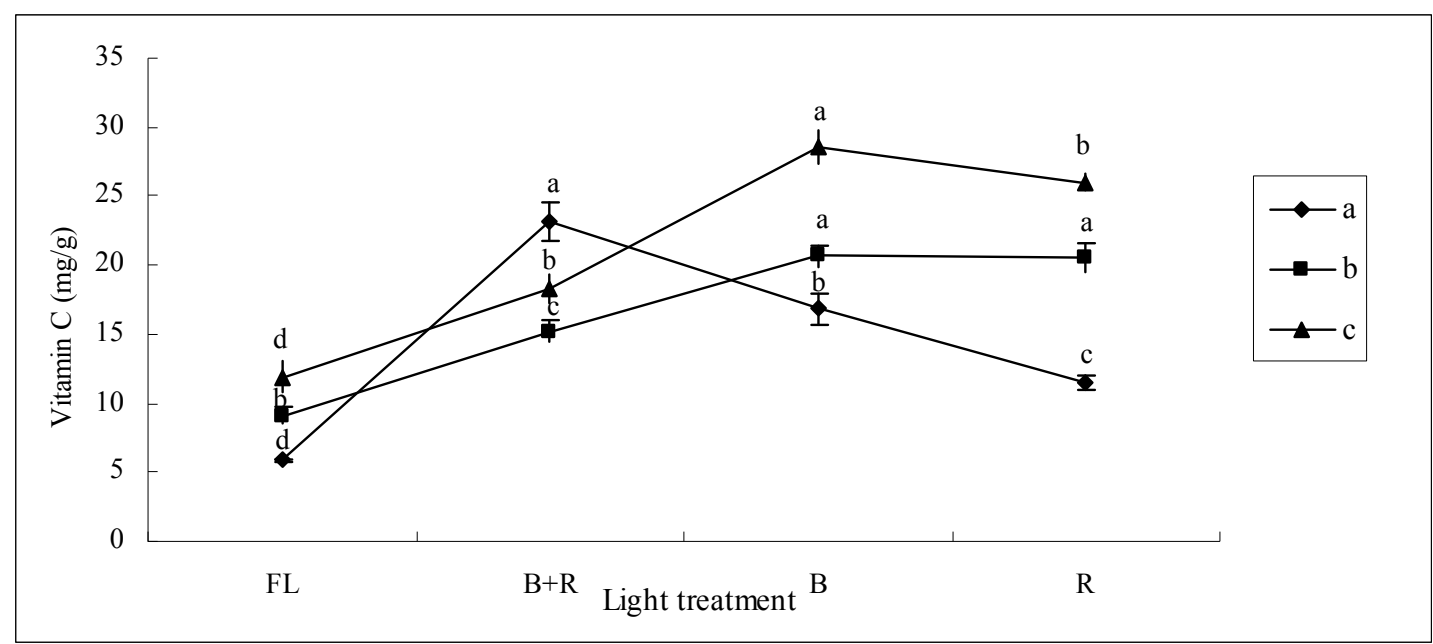

Figure 2. The effects of different lights on the vitamin $\mathrm{C}$ concentration of non-heading Chinese cabbage seedlings with different PPFD levels, growth under LEDs and FL at a PPFD level of $80 \mu \mathrm{mol} \mathrm{m}^{-2} \mathrm{~s}^{-1}$ for 60 days (a), initial growth at a PPFD level of $80 \mu \mathrm{mol} \mathrm{m}^{-2} \mathrm{~s}^{-1}$ for 30 days followed by sunlight for 30 days (b) and initial growth at a PPFD level of $80 \mu \mathrm{mol} \mathrm{m}^{-2} \mathrm{~s}^{-1}$ for 30 days followed by sunlight for 30 days and then weak light at 61 days until flowering (c)

Different letters within the column indicate significant differences at $\mathrm{P}<0.05$ according to Tukey's test.

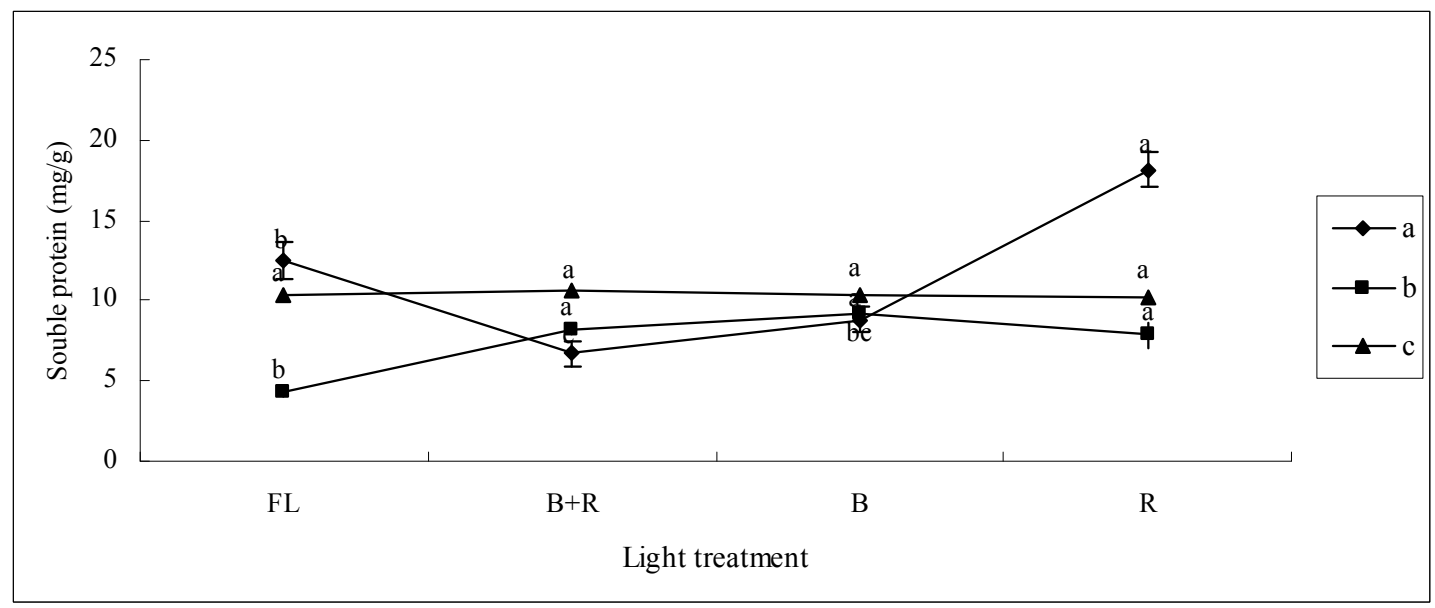

Figure 3. The effects of different lights on the soluble protein concentration of non-heading Chinese cabbage seedlings with different PPFD levels, growth under LEDs and FL at a PPFD level of $80 \mu \mathrm{mol} \mathrm{m}^{-2} \mathrm{~s}^{-1}$ for 60 days (a), initial growth at a PPFD level of $80 \mu \mathrm{mol} \mathrm{m}^{-2} \mathrm{~s}^{-1}$ for 30 days followed by sunlight for 30 days (b) and initial growth at a PPFD level of $80 \mu \mathrm{mol} \mathrm{m} \mathrm{m}^{-2}$ for 30 days followed by sunlight for 30 days and then weak light at 61 days until flowering (c)

Different letters within the column indicate significant differences at $\mathrm{P}<0.05$ according to Tukey's test. 


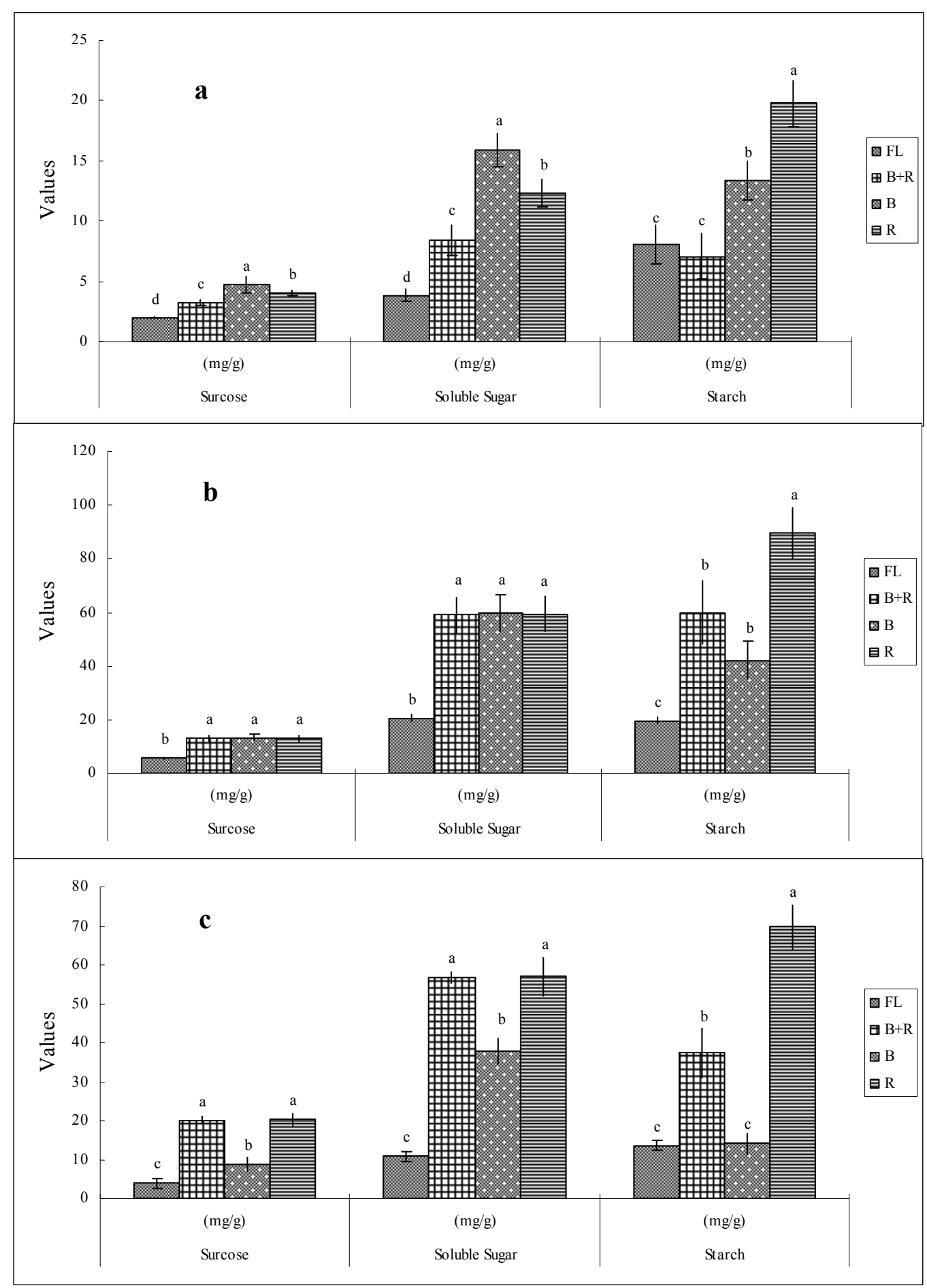

Figure 4. The effects of different lights on the photosynthesis production of non-heading Chinese cabbage seedlings with different PPFD levels, growth under LEDs and FL at a PPFD level of $80 \mu \mathrm{mol} \mathrm{m}^{-2} \mathrm{~s}^{-1}$ for 60 days (a), initial growth at a PPFD level of $80 \mu \mathrm{mol} \mathrm{m}^{-2} \mathrm{~s}^{-1}$ for 30 days followed by sunlight for 30 days (b) and initial growth at a PPFD level of $80 \mu \mathrm{mol} \mathrm{m} \mathrm{s}^{-2}$ for 30 days followed by sunlight for 30 days and then weak light at 61 days until flowering (c)

Different letters within the column indicate significant differences at $\mathrm{P}<0.05$ according to Tukey's test. 